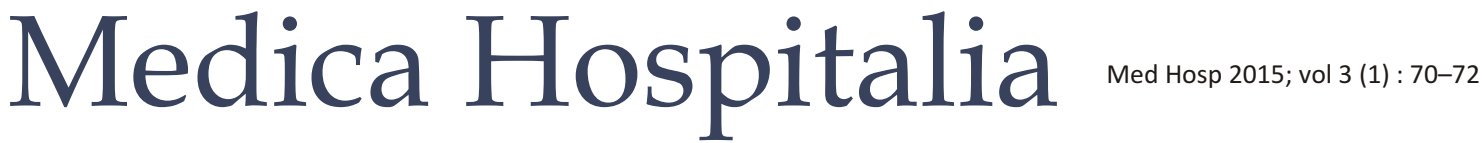

Clinical Practice

\section{Pengobatan Rasional pada Ulkus Kornea Bakteri}

\author{
Dina Novita \\ SMF IImu Kesehatan Mata Fakultas Kedokteran Universitas Diponegoro / RSUP Dr. Kariadi Semarang
}

\section{PENDAHULUAN}

Ulkus kornea merupakan salah satu penyakit pada mata yang sering menyebabkan morbiditas terutama di negara berkembang. ${ }^{1}$ Ulkus kornea merupakan kondisi yang dapat mengancam penglihatan, dan jika tidak diterapi dengan tepat, dapat mengakibatkan perforasi kornea, perluasan infeksi ke jaringan sekitarnya, dan endoftalmitis., ${ }^{2,3}$

Ulkus kornea merupakan peradangan pada kornea yang ditandai adanya infiltrat disertai defek epitel yang melibatkan stroma kornea dan terdapat jaringan nekrotik. ${ }^{3}$ Ulkus kornea dapat disebabkan oleh berbagai agen infeksi, salah satunya yaitu bakteri. Pemakaian lensa kontak merupakan penyebab utama ulkus kornea di negara maju sementara trauma merupakan penyebab utama ulkus kornea di negara berkembang. ${ }^{4}$

Angka kejadian ulkus kornea bakteri di RSUP Dr. Kariadi Semarang periode Januari 2009 - Desember 2013 adalah 181 kasus, dengan usia penderita 5-80 tahun, dan rasio perbandingan lelaki dan perempuan 2,7 : 1 . Mayoritas pekerjaan penderita adalah petani $(41,9 \%)$ dan buruh $(17,6 \%)$, dengan faktor risiko terbanyak oleh karena trauma $(93,9 \%)$. Penyebab terbanyak ulkus kornea di RSUP Dr. Kariadi berdasarkan hasil kultur adalah Staphylococcus aureus (13,8\%), diikuti Staphylococcus epidermidis dan Pseudomonas aeruginosa (masing-masing 8,84\%), Enterobacter aerogenes (4,42\%), Staphylococcus haemolyticus $(1,66 \%), S$. hominis $(1,1 \%)$, Streptococcus pneumoniae, Streptococcus faecium, Streptococcus viridans (masing-masing $0,55 \%$ ) dan sisanya tidak ditemukan pertumbuhan kuman (59,11\%). Pemeriksaan sensitivitas dari kultur yang positif menunjukkan bakteri gram positif sensitif terhadap vancomicin, aminoglikosida, dan moxifloxacin; sedangkan bakteri gram negatif sensitif terhadap fluorokuinolon, dan aminoglikosida. ${ }^{5}$

Penatalaksanaan ulkus kornea bakteri hendaknya memperhatikan pemilihan antibiotik yang tepat. Berikut ini merupakan pedoman pemakaian terapi antibiotik yang efektif : ${ }^{6}$
- Tegakkan diagnosis klinis dan laboratoris

- Pilih antibiotik yang sensitif terhadap mikroorganisme

- Pilih antibiotik dengan efek samping toksik yang minimal

- Berikan level obat yang adekuat pada tempat infeksi

- Pilih rute pemberian obat yang optimal

- Gunakan regimen dosis yang tepat

- Resepkan obat dengan memperkirakan berapa lama pemberian obat

- Efektifkan terapi obat dengan prosedur fisik, seperti melakukan debridement atau pengambilan eksudat purulen atau jaringan nekrotik

- Edukasi pasien

Pada banyak situasi klinik dimana banyak antibiotik digunakan, kuman patogen penyebab penyakit tidak diketahui pada saat terapi dimulai, atau bila kuman patogen diketahui, kepekaannya terhadap antibiotik tertentu tidak diketahui. Penggunaan antibiotik seperti ini merupakan terapi empirik, yaitu terapi yang berasal dari anggapan adanya infeksi, berdasarkan pengalaman dengan situasi klinis yang sama dibandingkan informasi spesifik tentang penyakit pasien. Prinsip dasar terapi empirik ialah bahwa pengobatan infeksi sebaiknya dilakukan sedini mungkin. Penundaan pemberian antibiotik sampai mendapatkan hasil kultur kuman dan tes kepekaan dapat mengakibatkan pasien mengalami penyakit serius. ${ }^{7}$

Pemberian terapi empirik harus sesuai dengan protokol yang jelas, yaitu (1) Menentukan diagnosis klinik suatu infeksi mikroba, (2) Mendapatkan bahan pemeriksaan laboratorium (spesimen diperiksa secara mikroskopis dengan metode pewarnaan gram dan jamur), (3) Menentukan diagnosis mikrobiologis, (4) Menentukan terapi empirik, (5) Melakukan pengobatan.

Pemilihan antibiotika yang rasional tergantung dari diagnosis dan identifikasi kuman penyebab., Diagnosis ditegakkan berdasarkan gambaran klinis. Agen penyebab infeksi dan gambaran klinis tidak selalu 


\begin{tabular}{|c|c|c|c|}
\hline \multicolumn{4}{|c|}{ Terapi untuk keratitis / ulkus kornea bakteri² } \\
\hline Organisme & Antibiotika & Dosis topikal & Dosis subkonjungtiva \\
\hline \multirow[t]{4}{*}{ Gram positif coccus } & Cefazolin & $50 \mathrm{mg} / \mathrm{mL}$ & $100 \mathrm{mg}$ dalam 0,5 ml \\
\hline & Vancomicin* & $25-50 \mathrm{mg} / \mathrm{mL}$ & $25 \mathrm{mg}$ dalam 0,5 ml \\
\hline & Moxifloxacin atau & 5 atau $3 \mathrm{mg} / \mathrm{mL}$ & Tidak tersedia \\
\hline & gatifloxacin & & \\
\hline \multirow[t]{3}{*}{ Gram negatif batang } & Tobramicin & $9-14 \mathrm{mg} / \mathrm{mL}$ & $20 \mathrm{mg}$ dalam $0,5 \mathrm{ml}$ \\
\hline & Ceftazidime & $50 \mathrm{mg} / \mathrm{mL}$ & $100 \mathrm{mg}$ dalam 0,5 ml \\
\hline & Fluorokuinolon & $3 \mathrm{mg} / \mathrm{mL}$ & Tidak tersedia \\
\hline Organisme (-) atau & Cefazolin dengan & $50 \mathrm{mg} / \mathrm{mL}$ & $100 \mathrm{mg}$ dalam 0,5 ml \\
\hline \multirow[t]{2}{*}{ multipel organisme } & tobramicin atau & 9-14 mg/mL & $20 \mathrm{mg}$ dalam $0,5 \mathrm{ml}$ \\
\hline & fluorokuinolon & 3 atau $5 \mathrm{mg} / \mathrm{mL}$ & Tidak tersedia \\
\hline \multirow[t]{4}{*}{ Gram negatif coccus } & Ceftriaxon & $50 \mathrm{mg} / \mathrm{mL}$ & $100 \mathrm{mg}$ dalam 0,5 ml \\
\hline & Ceftazidime & $50 \mathrm{mg} / \mathrm{mL}$ & \\
\hline & Moxifloxacin atau & 5 atau $3 \mathrm{mg} / \mathrm{mL}$ & \\
\hline & gatifloxacin & & \\
\hline \multirow[t]{2}{*}{ Mycobacteria } & Chlarithromicin & $19(24,4)$ & \\
\hline & Moxifloxacin atau & $19(24,4)$ & \\
\hline
\end{tabular}

Keterangan : *untuk spesies Staphylococcus yang resisten

berhubungan, sehingga penting untuk mendapatkan spesimen yang tepat untuk identifikasi bakteriologi dari agen penyebab. ${ }^{8}$ Klinisi harus mempertimbangkan untuk melakukan pemeriksaan mikrobiologi tersebut sebelum memberikan terapi anti mikroba untuk keratitis / ulkus kornea bakteri yang dicurigai. AAO (American Academy of Ophthalnmology) merekomendasikan pemeriksaan kultur untuk infiltrat yang mencapai sentral kornea, melibatkan stroma yang dalam, dan infiltrat dengan diameter $>2 \mathrm{~mm}^{2}$ Diagnosis definitif pada kasus ulkus kornea ditunjukkan oleh hasil kultur dan sensitivitas dari spesimen (scrapping / kerokan kornea). ${ }^{8}$

Tujuan untuk mencapai konsentrasi yang tinggi dari antibiotik dapat diperoleh dengan penetesan yang frekuen dari tetes antibiotik. Beberapa antibiotik berfungsi sebagai bakterisidal (yang mematikan mikroorganisme) dan bakteriostatik (yang menghambat multiplikasi bakteri). Beberapa obat bakteriostatik menjadi bakterisidal ketika diberikan dalam konsentrasi yang lebih tinggi seperti pada tetes mata. Penetrasi obat dapat ditingkatkan dengan penetesan obat yang lebih frekuen, peningkatan viskositas obat atau melalui penggunaan tetes mata fortified. ${ }^{8}$

Terapi pada ulkus kornea harus dimulai sebelum diagnosis definitif diperoleh untuk mengurangi bacterial load, dan meminimalkan penurunan visus. Terapi inisial menggunakan terapi empirik, dengan menggunakan obat topikal yang memiliki spektrum luas. Pada ulkus kornea secara umum, pengobatan monoterapi dengan fluorokuinolon topikal menghasilkan outcome yang sama dengan terapi kombinasi, oleh karena penetrasi yang baik dari kuinolon. Antibiotik tersebut harus diberikan setiap 30-60 menit dan frekuensi pemberiannya diturunkan sesuai dengan respon klinis. Pada kasus yang berat, pemberian antibiotik setiap 5 menit selama 30 menit untuk loading dose dapat mencapai konsentrasi terapi yang lebih cepat pada stroma kornea. ${ }^{2}$

Terapi kombinasi menggunakan agen yang melawan bakteri gram positif maupun gram negatif dapat digunakan sebagai alternatif lain untuk inisial terapi. Penggunaan terapi kombinasi diberikan jika monoterapi gagal atau jika gambaran klinis awal dari ulkus tersebut berukuran besar, mengancam visus, atau atipikal. $^{2}$

Antibiotik sistemik terutama fluorokuinolon memiliki penetrasi okuler yang baik. Antibiotik sistemik tersebut dapat diberikan bersama antibiotik topikal pada kasus perluasan infeksi ke sklera atau ke intraokuler. ${ }^{2}$

Respon terapi harus dipantau, yaitu secara klinis manifestasi umum dari infeksi pada pasien harus membaik dan keluhan / gejala harus berkurang. ${ }^{7}$ Ada beberapa tanda yang dapat digunakan sebagai petunjuk bahwa terjadi kemajuan hasil pengobatan yaitu : $:^{10}$

1. Terjadi re-epitelisasi kornea dan infiltrat berkurang 


\section{Respon p.m.n pada stroma berkurang}

3. Edema kornea berkurang

4. Respon di bilik mata depan berkurang

5. Ada kemajuan tajam penglihatan

Pada kasus yang tidak responsif terhadap terapi empiris, harus tetap dilakukan pemeriksaan kultur dengan penghentian pengobatan 12-24 jam sebelum melakukan pemeriksaan tersebut. ${ }^{2,11}$

Pada pengobatan yang efektif, sebagian besar keratitis bakteri akan memberikan hasil negatif pada pemeriksaan kultur, walaupun demikian terapi tetap dilanjutkan. Setelah infeksi dapat dikendalikan, antibiotik spektrum luas dapat diberikan sesuai dengan dosis terapi sampai epitel kornea menyembuh. ${ }^{2}$ Tidak perlu mengubah terapi jika keratitis / ulkus kornea berespon secara klinis / mengalami perbaikan dengan terapi inisial, walaupun hasil kultur menunjukkan bahwa terdapat resistensi mikroorganisme. ${ }^{12}$

\section{DAFTAR PUSTAKA}

1. Akter, Laila,et.al. Etiological agents of suppurative corneal ulcer: Study of 56 cases. Bangladesh J Med Microbiol 2009; 03 (01):33-6.

2. Skuta GL, Cantor LB, Cioffi GA. Basic and clinical science course. Sec. 8. External disease and cornea. San Fransisco : American Academy of Ophthalmology; 2013-2014:147-53.
3. Shaikh, Faheemullah,et.al. Pattern of microbes associated to keratitis in patients presenting at Liaquat University Hospital. Journal of Liaquat University of Medical and Health Science : September-December 2013: Vol.12: No.03.

4. Narsani, Ashok Kumar, et.al. Hospital-base epidemiology, risk factors and microbiological diagnosis of bacterial corneal ulcers. Int JOphthalmology 2009;2(4):362-6.

5. Pragnanda SH, Winarto, Novita D. Antibiotic sensitivity pattern of bacteria in bacterial corneal ulcer at dr Kariadi hospital : Bagian Ilmu Kesehatan Mata Universitas Diponegoro/ RSUP Dr. Kariadi Semarang; 2014.

6. Yolton DP, Haesaert SP. Anti infective drugs. Dalam : Fiscella RG, Holdeman NR, Prokopich SL, editors. 5th ed. Clinical ocular pharmacology. Philadelpia: Elsevier Inc; 2008:175-96.

7. Katzung BG. Basic and clinical pharmacology. 6th ed. San Fransisco : Appleton \& Lange; 1994: 784-791.

8. Garg A. Update on antibacterial therapy. Dalam : Garg A, Sheppard JD, Donnenfeld ED, Frielander M, editors. Clinical application of antibiotics and anti inflammatory drugs in ophthalmology. 1st ed. New Delhi : Jaypee; 2007: 87-89.

9. Winarto. Penanganan ulkus kornea secara optimal. Semarang. Dalam : Temu Ilmiah Perdami Jawa Tengah dan Bagian Mata FK Universitas Diponegoro. 2001:2

10. Sitompul R, Marsetio M, Asyari F, Sjamsoe S. Arah penatalaksanaan ulkus kornea bakteri. Understanding ocular infection and inflammation. Recent concept and basic science, clinical aspect and diagnostic course. Jakarta, 1999. Dept ophthalmology FK UI and Perdami Jaya, 33-41.

11. Sharma N, Vajpayee RB. Corneal ulcers. Diagnosis and management. 1sted. New Delhi: Jaypee Brothers; 2008: 73.

12. Kanski JJ. Clinical Ophthalmology. A systematic Approach.7th ed. London: Elsevier; 2011. 